\title{
PENGALAMAN MEMBACA KARYA SASTRA DALAM PERSPEKTIF PEMBELAJARAN
}

\author{
Maman Suryaman \\ Fakultas Bahasa dan Seni Universitas Negeri Yogyakarta \\ email:maman_suryaman@uny.ac.id
}

\begin{abstract}
Abstrak
Penelitian ini bertujuan untuk mengetahui perbedaan pengalaman mahasiswa membaca sastra sebelum mereka mengikuti perkuliahan berbasis strategi tugas dan presentasi dengan setelah mengikutinya di tiga kelas di Jurusan Pendidikan Bahasa dan Sastra Indonesia (JPBSI). Disain pembelajaran membaca sastra dirancang dengan menggunakan pendekatan praktik membaca berbasis tugas dan presentasi. Jenis penelitian yang digunakan adalah penelitian eksperimen semu. Disain penelitian yang dipilih adalah desain pretestposttest. Hasil penelitian sebagai berikut. Pertama, pengalaman mahasiswa membaca karya sastra berada di bawah standar membaca buku KTSP dan Kurikulum 2013. Kedua, strategi tugas dan presentasi berdampak positif terhadap peningkatan pengalaman mahasiswa membaca karya sastra dari 0 buku karya sastra menjadi sesuai standar Kurikulum JPBSI. Ketiga, selisih skor pengalaman membaca karya sastra setelah perlakuan signifikan.
\end{abstract}

Kata kunci: pengalaman membaca karya sastra, perspektif pembelajaran

\section{LITERARY READING EXPERIENCE IN THE LEARNING PERSPECTIVE}

\begin{abstract}
This study aimed to find out the difference in students' literary reading experience before they attended lectures based on assignment and presentation strategies and after they attended them in three classes in the Department of Indonesian Language and Literature (DILL). Literary reading learning was designed using a reading practice approach based on assignments and presentations. This was a quasi-experimental study using the pretest-posttest design. The results of the study were as follows. First, the students' literary reading experience was below the book-reading standards for the School-Based Curriculum and the 2013 Curriculum. Second, the assignment and presentation strategies had positive impacts on the improvement of the students' literary reading experience, from 0 literary works to a number satisfying the standard of the DILL Curriculum. Third, there was a significant difference in the score of literary reading experience after the treatment.
\end{abstract}

Keywords: literary reading experience, learning perspective 


\section{PENDAHULUAN}

Bangsa yang cerdas adalah bangsa yang memiliki peluang bagi terciptanya perubahan masyarakat ke arah peningkatan kesejahteraan, keadilan, kemanusiaan, dan spiritual keagamaan masyarakatnya. Salah satu komponen penting bagi terciptanya kecerdasaan bangsa adalah membaca. Keberaksaraan, budaya menulis, kompetensi berpikir, dan kecerdasan rohani akan tumbuh melalui membaca.

Dengan melihat fakta saat ini upaya untuk mencapai Visi Indonesia Emas 2045 tanpa didukung sumber daya manusia yang tangguh serta sarana dan prasarana yang memadai amatlah sulit. Apalagi hingga saat ini Indonesia belum termasuk ke dalam 10 besar ekonomi dunia. Salah satu penyebabnya menurut Soedjiarto (2008:20-21) adalah sistem pendidikan kita tanpa buku. Artinya, manusia yang bermoral, berdisiplin, beretos kerja tinggi, dan mampu menguasai dan menerapkan ipteks dan demokratisasi serta bertanggung jawab tidak dapat dilahirkan oleh sistem pendidikan tanpa buku. Dalam publikasi UNESCO (2005) pendidikan yang demikian tidak akan dapat diharapkan untuk dapat menunjang pembangunan bangsa, melainkan sebaliknya, yakni akan melahirkan masalahmasalah baru, seperti unprepared and unskilled educated young.

Perubahan kurikulum baru di Jurusan Pendidikan Bahasa dan Sastra Indonesia (selanjutnya disingkat JPBSI) menghasilkan satu mata kuliah baru, yakni membaca sastra. Pemunculan mata kuliah ini didasari oleh keluhan dosen atas kinerja mahasiswa terkait dengan rendahnya pengalaman membaca karya sastra. Hasil survei dalam berbagai perkuliahan bersastra, ratarata mahasiswa amat sedikit memiliki peng- alaman membaca sastra. Survey yang dilakukan terhadap mahasiswa semester I dalam kuliah membaca sastra pun sama, yakni nol membaca sastra saat di sekolah. Kondisi ini menuntut upaya untuk menyiasati agar mahasiswa semakin berpengalaman membaca karya sastra.

Berdasarkan latar belakang ini, dirancang suatu perkuliahan membaca sastra berbasis tugas dan presentasi. Masalah yang menjadi fokus penelitian ini adalah terkait dengan pembelajaran membaca sastra dalam mata kuliah membaca sastra ditinjau dari penerapan strategi berbasis tugas dan presentasi. Tujuan penelitian ini adalah untuk mengetahui perbedaan pengalaman membaca sastra sebelum dan setelah menggunakan perkuliahan berbasis strategi tugas dan presentasi pada empat kelas di Jurusan Pendidikan Bahasa dan Sastra Indonesia (selanjutnya ditulis PBSI) Fakultas Bahasa dan Seni Universitas Negeri Yogyakarta (selanjutnya ditulis FBS UNY).

Secara teoretis pengajaran sastra akan lebih efektif jika mahasiswa secara langsung mengalami sendiri untuk membaca karya. Hal ini didasari oleh asumsi yang dikemukakan oleh Effendi (1982:70) bahwa pengajaran sastra pada hakikatnya diarahkan pada kegiatan apresiasi sastra. Apresiasi sastra adalah kegiatan menggauli cipta sastra dengan sungguh-sungguh sampai menimbulkan pengertian, penghargaan, kepekaan pikiran kritis, dan kepekaan perasaan yang baik terhadap cipta sastra. Berdasarkan batasan ini, tujuan berapresiasi adalah tumbuhnya pengertian, penghargaan, kepekaan pikiran kritis, dan kepekaan perasaan yang baik terhadap cipta sastra pada diri apresiator.

Kegiatan apresiasi meliputi membaca beragam karya sastra, mempelajari teori 
sastra, mempelajari esei dan kritik sastra, serta mempelajari sejarah sastra. Di samping itu, perlu pula dilakukan kegiatan pendokumentasian atas informasi mengenai karya sastra serta kegiatan kreatif, yakni menulis karya sastra dan menulis bahasan terhadap karya sastra. Kegiatan-kegiatan seperti ini tentulah akan mengatasi kendala kurang tersedianya buku-buku sastra di perpustakaan sekolah.

Kegiatan pendokumentasian dan kegiatan kreatif itu dilihat dari segi pembelajaran ditujukan untuk meningkatkan apresiasi terhadap sastra agar siswa memiliki kepekaan terhadap sastra yang baik dan bermutu yang akhirnya berkeinginan membacanya. Dampak penyerta dari tingkat apresiasi karya sastra yang adalah tumbuhnya kebiasaan membaca yang akhirnya mampu meningkatkan pemahaman dan pengertian tentang manusia dan kemanusiaan, mengenal nilai-nilai, mendapatkan ide-ide baru, meningkatkan pengetahuan sosial budaya, berkembangnya rasa dan karsa, serta terbinanya watak dan kepribadian. Di sisi lain, mahasiswa juga akan terbantu mengenai bagaimana mendapatkan buku-buku sastra yang bermutu. Selama ini yang menjadi persoalan adalah tidak semua sekolah memiliki perpustakaan, padahal penyediaan bahan bacaan yang praktis dan efisien adalah berupa perpustakaan.

Salah satu bentuk pengajaran membaca sastra di JPBSI adalah melalui kewajiban bagi mahasiswa untuk membaca karya-karya sastra bermutu. Sesungguhnya kewajiban ini juga diterapkan di sekolah. Di seluruh negara di dunia, sekolah mewajibkan para siswanya untuk membaca buku sastra (bukan bertujuan supaya siswa jadi sastrawan, tetapi agar terbentuk dan terlatih kebiasaan serta kesenangan membaca buku pada umumnya). Kewajiban ini dituangkan di dalam standar isi (SI) bahwa siswa SMP harus membaca buku sastra minimal 10 buah dan siswa SMA harus membaca buku sastra minimal 15 buah.

Dari pengamatan Taufiq Ismail (1996) di beberapa negara Asia Tenggara seperti Malaysia, Thailand, Singapura, dan Brunei Darussalam, siswa SMA wajib membaca dan memberikan ulasan terhadap 5-7 buku sastra dalam 3 tahun. Di Rusia Soviet, Kanada, Jepang, dan Swiss, kewajiban tersebut adalah 12-15 judul buku, sedangkan Jerman Barat, Perancis, Belanda, dan Amerika Serikat masing-masing mewajibkan 22, 30, 30 dan 32 judul. AMS Hindia Belanda (sebelum 1942) mewajibkan siswa membaca 25 judul karya sastra, setaraf dengan Eropa dan Amerika hari ini.

Di zaman Republik Indonesia, dengan kriteria kurikulum, tersedianya buku di perpustakaan sekolah, buku dibaca tamat, siswa mengulasnya dan lalu diujikan, dibandingkan dengan negara-negara di atas, ternyata di SMA Indonesia siswa membaca 0 (nol) buku sastra. Hal mengejutkan ini sudah berlangsung lebih dari 60 tahun sejak 1943. Siswa Indonesia, untuk bisa lulus, cukup membaca ringkasan atau sinopsis novel, dan dengan demikian kenal nama-nama tokoh dan alur cerita, tetapi tidak pernah menikmati karya sastra secara utuh. Dengan demikian, generasi muda Indonesia tidak mendapatkan manfaat pencerahan dan kecendekiaan dari karya sastra yang otentik.

Tidak adanya kewajiban membaca buku sastra seperti sebelum 1943 terutama disebabkan tidak disediakannya buku-buku sastra di perpustakaan sekolah. Hal ini me- 
rupakan kepincangan pertumbuhan peradaban bangsa Indonesia yang tertinggal lama dan luar biasa parahnya.

Kondisi tersebut akan berpengaruh terhadap kesiapan siswa ketika memasuki tahap di perguruan tinggi. Tidak terbentuknya kebiasaan membaca sastra di sekolah tergambar pula di perguruan tinggi. Rata-rata mahasiswa JPBSI tidak membaca sastra saat di sekolah. Akibatnya, pada saat menempuh kuliah mahasiswa juga tidak terbiasa dan tidak termotivasi untuk membaca. Adapun jika membaca, masih pada tahap untuk pemenuhan tugas mata kuliah. Membaca secara budaya belum terjadi pada kalangan mahasiswa JPBSI.

Buku memiliki peran strategi dalam proses pendidikan, ditunjang lagi dengan berbagai kenyataan bahwa sampai sekarang buku tidak dapat tergantikan posisinya oleh media lain. Buku juga merupakan media pendidikan yang murah dan dapat dipelajari kembali kapan saja serta di mana saja dengan keuntungan positif, seperti untuk mengasuh, memelihara, dan mengembangkan pikiran, imajinasi, serta kepribadian. Namun, buku juga dapat melumpuhkan atau merusak pikiran, imajinasi, serta kepribadian jika isinya buruk dan tidak sesuai kriteria. Perlulah para mahasiswa, siswa, dan guru membaca buku yang secara khusus mengajarkan bagaimana cara membaca (Adler dan van Doren, 2007:13). Pembentukan yang baik dapat dimulai dengan proses pembacaan secara rutin dengan jumlah yang banyak.

Pembentukan proses pembiasaan membaca sastra dengan jumlah yang banyak dapat dilakukan melalui suatu strategi secara terencana. Strategi yang terencana ini diejawantahkan melalui perubahan kurikulum di JPBSI dengan membuat satu mata kuliah baru bernama membaca sastra. Fenomena yang muncul dan selalu dikeluhkan dosen pengampu mata kuliah sastra maupun nonsastra adalah rendahnya wawasan bacaan (termasuk bacaan sastra) para mahasiswa.

Pengalaman awal yang rendah pada para mahasiswa terkait dengan membaca sastra menjadi suatu pemikiran terpenting untuk mencari strategi yang efektif agar mula-mula mahasiswa tertarik untuk membaca tanpa dibebani oleh kegiatan-kegiatan analitis. Artinya, sebelum mahasiswa disuguhi dengan kegiatan analitis dan mempelajari teori-teori sastra yang masih asing bagi mereka, perlulah ada upaya untuk membina kegiatan apresiasi berupa membaca sastra. Untuk mencapai kondisi semacam ini keakraban mahasiswa dengan karya sastra mutlak diperlukan. Upaya ini sejalan dengan persiapan dosen dalam merancang perkuliahan apresiasi sastra melalui strategi berbasis tugas dan presentasi. Pemilihan strategi ini harus sesuai dengan karakteristik pengajaran sastra itu sendiri. Tugas dan presentasi sebagai salah satu strategi yang memungkinkan mahasiswa aktif melakukan kegiatan mandiri dan dipertanggungjawabkan melalui presentasi.

Strategi tugas dan presentasi merupakan strategi yang dipadukan sebagai sebuah paket. Melalui penugasan, mahasiswa wajib membaca karya sastra (puisi, cerpen, dan novel). Hasil membaca berupa tanggapan tertulis dalam bentuk kesan atas karya tersebut. Tanggapan tertulis tersebut kemudian dipresentasikan di dalam setiap perkuliahan.

Terdapat empat hipotesis kerja penelitian yang didasarkan atas kajian teori. Keempat hipotesis tersebut dirumuskan 
dalam satu rumusan, yakni pengalaman membaca sastra mahasiswa kelas A, B, $C$, dan D setelah mengikuti perkuliahan membaca sastra dengan strategi penugasan dan presentasi lebih baik dibandingkan dengan sebelum mengikuti perkuliahan membaca sastra dengan strategi penugasan dan presentasi.

\section{METODE}

Jenis penelitian yang digunakan adalah penelitian eksperimen semu. Alasan pemilihan jenis penelitian ini adalah tidak semua variabel yang muncul dari kondisi eksperimen dapat diatur atau dikontrol secara ketat. Dalam hal pengalaman membaca yang dipengaruhi banyak faktor memberikan karakteristik bahwa variabel ini sulit untuk dikontrol secara ketat. Alasan lain adalah bahwa jenis penelitian ini dilakukan tanpa ada pengelompokan baru.

Tujuan penelitian eksperimen semu adalah untuk mengkaji ada tidaknya hubungan sebab akibat antara pengalaman membaca karya sastra dengan strategi berbasis tugas dan presentasi serta berapa besar hubungan sebab akibat tersebut. Berdasarkan tujuan ini dirancang suatu perlakuan atas kelompok subjek untuk membuktikan hipotesis. Disain penelitian yang dipilih adalah desain prates-pascates.

\begin{tabular}{|ll|}
\hline O1-ABCD & XO2-ABCD \\
\hline
\end{tabular}

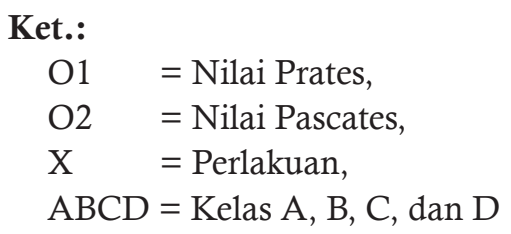

\section{Bagan 1 Disain Eksperimen}

Tahapan-tahapan penelitian meliputi: penyusunan instrumen penelitian, pengumpulan informasi tentang kompetensi bersastra yang telah dimiliki mahasiswa semester dua yang menempuh mata kuliah membaca sastra melalui tes (prates), memberikan perlakuan berdasarkan rancangan pembelajaran membaca karya sastra berbasis tugas dan presentasi, dan mengumpulkan informasi tentang kompetensi bersastra yang sudah dimiliki mahasiswa semester dua yang menempuh mata kuliah membaca sastra melalui tes (pascates).

Penelitian dilakukan di empat kelas membaca sastra di JPBSI semester ganjil 2015/2016. Pada awalnya, sesuai dengan presensi kehadiran, jumlah per kelas sebanyak 20 mahasiswa sehingga jumlah total empat kelas adalah 80 mahasiswa. Namun, setelah masuk ke dalam kelas, terdapat perubahan jumlah mahasiswa per kelas yang disebabkan oleh mahasiwa tidak aktif (tidak mengikuti kuliah) dan alasan pribadi mahasiswa yang kadang masuk kadang tidak masuk. Oleh karena itu, tidak semua mahasiswa dijadikan sebagai bagian dalam eksperimen ini. Berikut ini adalah jumlah kelas dan mahasiswa yang dijadikan sebagai subjek eksperimen.

\section{Tabel 1 Subjek Penelitian}

\begin{tabular}{ccc} 
No. & Kelas & Jumlah \\
\hline 1. & A & 19 \\
2. & B & 14 \\
3. & C & 15 \\
4. & D & 11 \\
Jumlah & 4 & 59 \\
\hline
\end{tabular}

Data diperoleh melalui angket. Penyusunan angket didasarkan atas kriteri yang ada dalam Rencana Pembelajaran Semester (RPS), yakni mahasiswa wajib membaca 
minimal 10 novel, 10 kumpulan cerpen, 10 kumpulan puisi, dan 5 naskah drama. Namun, karena alasan waktu yang terbatas, jenis karya sastra drama tidak dimasukkan ke dalam perlakuan. Oleh karena karya yang harus dibaca tidak ditentukan, angket yang disusun bersifat terbuka. Artinya, angket berbentuk angket terbuka sesuai kriteria dan responden mengisikan data berdasarkan pengalamannya.

Pengolahan data angket dilakukan dengan memberikan skor 1 pada setiap responden yang mengisi pengalaman membaca kumpulan puisi, novel, dan cerpen dengan masing-masing isian sebanyak 10 butir kali 3 genre sehingga total skor 30 . Skor total tertinggi sebesar 30 dan terendah 0 . Skor tersebut kemudian dikonversi ke dalam rentang 100 dengan rumus sebagai berikut.

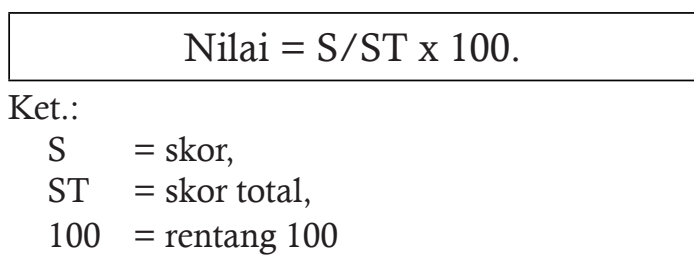

Data dianalisis secara statistik deskriptif dan inferensial. Tahap pertama data diolah secara statistik deskriptif untuk mendapatkan informasi jumlah dan rerata karya yang sastra yang dibaca, baik sebelum maupun sesudah perlakuan. Tahap kedua, untuk membandingkan data prates dengan pascates untuk setiap kelas dianalisis dengan uji beda. Untuk mengambil keputusan mengenai ada-tidaknya perbedaan secara signifikan, dasarnya adalah nilai probabilitas berikut ini.

Jika probabilitas $>0,05$, Ho diterima. Jika probabilitas $\leq 0,05$, Ho ditolak.

\section{Bagan 2 Nilai Probabilitas}

Data penelitian yang diperoleh divalidasi dari hasil penelitian. Kriteria ahli yang digunakan untuk validasi ahli adalah pakar di bidang pembelajaran sastra. Validator yang dimaksud adalah Dr. Anwar Efendi, M.Si.

\section{HASIL DAN PEMBAHASAN}

Pada bagian hasil penelitian ini disajikan beberapa jawaban atas pertanyaan penelitian. Pertama, data terkait dengan pengalaman membaca karya sastra mahasiswa yang diolah secara statistik deskriptif. $K e d u a$, data terkait dengan pengalaman membaca karya sastra mahasiswa yang diolah secara statistik inferensial.

\section{Hasil}

Data keseluruhan responden adalah 59 yang terbagi dalam empat kelas, yakni kelas A, B, C, dan D. Berikut ini adalah paparan deskriptif atas pengalaman membaca karya sastra.

Tabel 2 Pengalaman Membaca Sastra sebelum dan sesudah Perlakuan Kelas PBSI-A

\begin{tabular}{|c|c|c|c|c|c|c|c|c|c|c|}
\hline \multirow{2}{*}{ Kelas } & \multirow{2}{*}{$\mathrm{R}$} & \multirow{2}{*}{$\mathrm{J}-\mathrm{R}$} & \multicolumn{3}{|c|}{ KSD } & \multirow{2}{*}{ TKSD } & \multicolumn{3}{|c|}{ KSD } & \multirow{2}{*}{ TKSD } \\
\hline & & & $\mathrm{P}$ & $\mathrm{C}$ & $\mathrm{N}$ & & $\mathrm{P}$ & $\mathrm{C}$ & $\mathrm{N}$ & \\
\hline \multirow[t]{2}{*}{ PBSI-A } & 19 & JBKS & 5 & 3 & 137 & 145 & 143 & 73 & 177 & 393 \\
\hline & & Rerata & 0.26 & 0.16 & 7.21 & 7.63 & 7.53 & 3.84 & 9.32 & 20.68 \\
\hline \multirow[t]{2}{*}{ PBSI-B } & 14 & JBKS & 1 & 13 & 53 & 67 & 5 & 19 & 141 & 165 \\
\hline & & Rerata & 0.07 & 0.93 & 3.78 & 4.78 & 0.36 & 1.36 & 10.5 & 11.78 \\
\hline \multirow[t]{2}{*}{ PBSI-C } & 15 & JBKS & 101 & 25 & 106 & 232 & 79 & 41 & 154 & 274 \\
\hline & & Rerata & 6.73 & 1.67 & 7.07 & 15.47 & 5.27 & 2.73 & 10.27 & 18.27 \\
\hline \multirow[t]{2}{*}{ PBSI-D } & 11 & JBKS & 13 & 19 & 100 & 131 & 31 & 20 & 113 & 154 \\
\hline & & Rerata & 1.18 & 1.73 & 9.09 & 11.91 & 2.82 & 1.82 & 10.27 & 14 \\
\hline
\end{tabular}

Ket.: $\mathrm{R}=$ Responden J-R = Jumlah dan Rerata, KSD = Karya Sastra yang Dibaca, TKSD = Total Karya Sastra yang Dibaca 
Berdasarkan hasil sebaran angket diperoleh data mengenai pengalaman membaca sastra sebelum dan sesudah perlakuan. Pengalaman mahasiswa membaca buku sastra puisi dan cerita pendek sebelum perlakuan pada kelas A dan B berada di bawah satu buku (puisi 0.26 buku dan cerita pendek $0.16 \mathrm{buku}$ ) atau nol buku, sedangkan pengalaman mahasiswa membaca buku sastra puisi dan cerita pendek sebelum perlakuan pada kelas $\mathrm{C}$ dan $\mathrm{D}$ berada di bawah dua buku atau hanya satu buku. Pengalaman mahasiswa membaca buku sastra novel sebelum perlakuan pada semua kelas berada dalam kisaran tiga sampai sembilan buku. Jika dilihat dari seluruh buku karya sastra yang dibaca, reratanya berada pada kisaran empat sampai dengan 15 buku karya sastra dengan rincian 7.21 buku kelas A, 4.78 buku kelas B, 15.47 buku kelas C, dan 11.91 kelas D.
Pengalaman membaca karya sastra setelah perlakuan untuk buku puisi dan cerita pendek secara umum meningkat tetapi tidak menonjol karena masih ada yang nol buku dan di bawah tiga buku. Untuk novel pengalaman mahasiswa membaca karya sastra cenderung meningkat dalam kisaran 9 sampai dengan di bawah 10 buku. Kenderungan buku karya sastra yang dibaca secara total mengalami peningkatan menjadi 14 sampai dengan di bawah 21 buku (20 buku) dibaca per mahasiswa. Artinya, kondisi awal pengalaman membaca sastra mahasiswa masih sangat rendah dibandingkan dengan setelah perlakuan. Dalam waktu hanya satu semester mahasiswa membaca antara 14 sampai dengan 24 buku karya sastra, sedangkan selama di sekolah dan satu semester kuliah hanya membaca empat sampai dengan 15 buku karya sastra.

Tabel 3. Distribusi Skor Pengalaman Membaca Sastra Prates dan Pascates Kelas A, B. C. Dan D

\begin{tabular}{llllll}
\hline Pasangan & Variabel & Rerata & N & SB & Variasi \\
\hline Pas. 1 & Prates Membaca Sastra Kelas A & 22,45 & 19 & 1,09 & 119,42 \\
& Pascates Membaca Sastra Kelas A & 67,20 & 19 & 1,50 & 226,08 \\
Pas. 2 & Prates Pengalaman Membaca Sastra Kelas B & 15,19 & 14 & 1,17 & 136,47 \\
& Pascates Pengalaman Membaca Sastra Kelas B & 34,07 & 14 & 1,25 & 156,42 \\
Pas. 3 & Prates Pengalaman Membaca Sastra Kelas C & 48,73 & 15 & 1,58 & 249,59 \\
& Pascates Pengalaman Membaca Sastra Kelas C & 57,21 & 15 & 2,55 & 650,17 \\
Pas. 4 & Prates Pengalaman Membaca Sastra Kelas D & 39,19 & 11 & 9,82 & 96,55 \\
& Pascates Pengalaman Membaca Sastra Kelas D & 49,60 & 11 & 1,40 & 197,63 \\
\hline
\end{tabular}

Ket.: $\mathrm{N}=$ jumlah responden, $\mathrm{SB}=$ simpangan baku

Rerata skor pengalaman membaca sastra kelas A sebelum perlakuan lebih kecil dibandingkan dengan setelah mendapatkan perlakuan dengan selisih skor sebesar 44,75. Artinya, strategi tugas dan presentasi memberikan dampak positif dalam hal pengalaman membaca sastra. Hal ini sejalan de- ngan peta pengalaman membaca mahasiswa dari angket yang juga mengalami peningkatan jumlah buku karya sastra yang dibaca.

Pengalaman membaca mahasiswa pada kelas B dengan jumlah jumlah 14 mahasiswa sebelum perlakuan memberikan gam- 
baran yang sama dengan kelas A, yakni buku kumpulan puisi dan cerita pendek di bawah satu buku (puisi 0.07 buku dan cerita pendek $0.93 \mathrm{buku}$ ), sedangkan novel 3.78 buku. Total per mahasiswa untuk seluruh jenis buku karya sastra sebanyak 4.78 buku. Data ini lebih rendah dibandingkan dengan kelas A. Pengalaman membaca karya sastra setelah perlakuan dengan urutan yang sama meningkat menjadi 0.36 untuk buku puisi per mahasiswa (masih di bawah satu buku), cerita pendek 1.36 buku, dan novel 10.5 buku dengan total untuk seluruh karya sastra sebanyak 11.78 buku yang dibaca per mahasiswa. Artinya, kondisi awal pengalaman membaca sastra di kelas B lebih rendah dibandingkan dengan kelas A dan lebih rendah dibandingkan dengan setelah perlakuan. Dalam waktu hanya satu semester mahasiswa membaca 11.78 buku karya sastra, sedangkan selama mahasiswa di sekolah sampai kuliah satu semester hanya membaca 4.78 buku.

Rerata skor pengalaman membaca sastra kelas B sebelum perlakuan adalah 15,19 dengan simpangan baku sebesar 1,17 dan variansinya sebesar 136,47 . Adapun rerata pengalaman membaca sastra kelas B setelah perlakuan adalah 34,07 dengan simpangan baku sebesar 1,25 dan variansinya sebesar 156,42. Artinya, terdapat peningkatan skor rerata pada kelas B sebesar 18,88 setelah mendapatkan perlakuan mengikuti perkuliahan membaca karya sastra dengan strategi penugasan dan presentasi. Berdasarkan peningkatan tersebut dengan strategi tugas dan presentasi memberikan dampak positif dalam hal pengalaman membaca karya sastra. Hal ini sejalan dengan peta pengalaman membaca karya sastra dilihat dari jumlah buku sastra yang dibaca. Semakin banyak buku karya sastra yang dibaca, semakin tinggi dampaknya bagi pengalaman membaca karya sastra.

Pengalaman membaca mahasiswa pada kelas $\mathrm{C}$ dengan jumlah jumlah 15 mahasiswa, buku kumpulan puisi yang dibaca sebelum perlakuan sebesar hanya 6.73; cerita pendek 1.67 buku; dan novel 7.07 buku. Total per mahasiswa untuk seluruh jenis buku karya sastra sebanyak 15.47 buku. Pengalaman membaca setelah perlakuan dengan urutan yang sama mengalami penurunan menjadi 5.27 untuk buku puisi per mahasiswa, sedangkan untuk buku cerita pendek meningkat 2.73 buku, dan novel 10.27 buku dengan total untuk seluruh karya sastra sebanyak 18.27 buku yang dibaca per mahasiswa. Artinya, kondisi awal pengalaman membaca sastra dibandingkan dengan setelah perlakuan tidak jauh berbeda, yakni dari 15.47 buku karya sastra menjadi 18.27 buku karya sastra.

Rerata pengalaman membaca sastra kelas $C$ sebelum perlakuan adalah 48,73 dengan simpangan baku sebesar 1,58 dan variansinya sebesar 249,59. Adapun rerata pengalaman membaca sastra kelas $C$ setelah perlakuan adalah 57,21 dengan simpangan baku sebesar 2,55 dan variansinya sebesar 650,17. Artinya, terdapat peningkatan skor rerata pada kelas $C$ sebesar 8,48 setelah mendapatkan perlakuan mengikuti perkuliahan membaca sastra dengan strategi penugasan dan presentasi. Namun, peningkatannya tidak signifikan. Hal ini sejalan juga dengan perbedaan jumlah membaca karya sastra antara sebelum perlakuan dengan setelah perlakuan yang relatif sedikit.

Pengalaman membaca mahasiswa pada kelas D dengan jumlah 11 mahasiswa, buku kumpulan puisi yang dibaca sebelum per- 
lakuan sebanyak 1.18; cerita pendek 1.73 buku; dan novel 9.09 buku. Total per mahasiswa untuk seluruh jenis buku karya sastra sebanyak 11.91 buku. Pengalaman membaca setelah perlakuan dengan urutan yang sama mengalami peningkatan menjadi 2.82 untuk buku puisi per mahasiswa, sedangkan untuk buku cerita pendek meningkat menjadi 1.82 buku, dan novel 10.27 buku dengan total untuk seluruh karya sastra sebanyak 14 buku yang dibaca per mahasiswa. Artinya, kondisi awal pengalaman membaca sastra hanya 11.91 buku dibandingkan dengan setelah perlakuan. Setelah perlakuan selama satu semester, pengalaman membaca sastra mahasiswa mencapai 14 buku karya sastra.

Rerata pengalaman membaca sastra kelas D sebelum perlakuan adalah 39,19 dengan simpangan baku sebesar 9,82 dan variansinya sebesar 96,55. Adapun rata- rata pengalaman membaca sastra kelas D setelah perlakuan adalah 49,60 dengan simpangan baku sebesar 1,40 dan variansinya sebesar 197,63. Artinya, terdapat peningkatan skor rerata pada kelas D sebesar 10,41 setelah mendapatkan perlakuan mengikuti perkuliahan membaca sastra dengan strategi penugasan dan presentasi. Berdasarkan peningkatan tersebut dengan mengikuti perkuliahan membaca sastra dengan strategi penugasan dan presentasi memberikan dampak positif dalam hal pengalaman membaca sastra walaupun peningkatannya tidak signifikan.

Sesuai dengan metode yang digunakan, hipotesis penelitian diuji dengan uji-t. Hal ini dilakukan untuk mengetahui perbedaan nyata rata-rata antarvarian. Pada Tabel 4 disajikan perbandingan skor dari masingmasing kelompok dan rerata skor kelompok.

Tabel 4. Perbandingan Skor

\begin{tabular}{lcccccccc}
\hline \multirow{2}{*}{ Kelas } & \multicolumn{2}{c}{ Kelas A } & \multicolumn{2}{c}{ Kelas B } & \multicolumn{2}{c}{ Kelas C } & \multicolumn{2}{c}{ Kelas D } \\
Data & Prates & Pascates & Prates & Pascates & Prates & Pascates & Prates & Pascates \\
\hline $\mathrm{N}$ & 19 & 19 & 18 & 18 & 19 & 19 & 17 & 17 \\
Nilai Tertinggi & 40 & 83,3 & 46,7 & 46,7 & 83,3 & 100 & 53,3 & 80 \\
Nilai Terendah & 10 & 26,7 & 0 & 10 & 26,7 & 10 & 20 & 20 \\
Nilai Rerata & 22,4 & 67,2 & 15,2 & 34,1 & 48,7 & 57,2 & 39,2 & 49,6 \\
Nilai Tengah & 16,7 & 73,3 & 13,3 & 40 & 43,3 & 56,7 & 40 & 46,7 \\
Modus & 33,3 & 76,7 & 10 & 40 & 33,3 & 56,7 & 43,3 & 46,7 \\
Simpangan Baku & 1,092 & 1,503 & 1,168 & 1,250 & 1,579 & 2,549 & 9,825 & 1,405 \\
\hline
\end{tabular}

Tabel 4 merupakan deskripsi distribusi skor dari keempat kelas yang memiliki jumlah responden 59. Dari Tabel 4 diketahui bahwa nilai tertinggi keempat kelas adalah
100 , sedangkan yang terendah adalah 0 . Tabel tersebut menunjukkan keberagaman skor pengalaman membaca karya sastra pada mahasiswa.

Tabel 5. Rerata Skor Kelompok

\begin{tabular}{|c|c|c|c|c|c|}
\hline Rerata $\quad$ Kelas & Kelas A & Kelas B & Kelas C & Kelas D & Jumlah \\
\hline Rerata Prates & 22,4 & 15,2 & 48,7 & 39,2 & 31,37 \\
\hline Rerata Pascates & 67,2 & 34,1 & 57,2 & 49,6 & 50,02 \\
\hline Skor Perolehan & 44.8 & 18.9 & 8.5 & 10.4 & 18.65 \\
\hline
\end{tabular}


Rerata skor terendah sebelum perlakuan dialami oleh mahasiswa Kelas A sebesar 22.4, sedangkan rerata skor tertinggi dialami oleh mahasiswa Kelas C. Pengalaman membaca karya sastra sebelum perlakuan pada Kelas A lebih rendah dibandingkan dengan kelas lainnya, yakni B, C, dan D. Pengalaman membaca karya sastra sebelum perlakuan pada Kelas C lebih tinggi dibandingkan dengan kelas lainnya, yakni A, B, dan D.

Rerata skor terendah setelah perlakuan dialami oleh mahasiswa Kelas B sebesar 34,1 sedangkan rerata skor tertinggi dialami oleh mahasiswa Kelas A sebesar 67,2 . Pengalaman membaca setelah perlakuan pada Kelas B lebih rendah dibandingkan dengan kelas lainnya, yakni A, C, dan D. Pengalaman membaca karya sastra tertinggi setelah perlakuan dialami kelas A dibandingkan dengan kelas lainnya, yakni D, C, dan B.

Rerata total pengalaman membaca karya sastra sebelum perlakuan sebesar 31,37, sedangkan rerata pengalaman membaca karya sastra setelah perlakuan sebesar 50,02. Selisih skor antara sebelum perlakuan dengan setelah perlakuan tertinggi diraih oleh kelas A sebesar 44.8, sedangkan terendah kelas $C$ sebesar 8.5. Selisih skor total antara sebelum perlakuan dengan setelah perlakuan sebesar 18,65. Artinya, strategi tugas dan presentasi memberikan sumbangan positif bagi perbaikan dalam pengalaman membaca sastra mahasiswa PBSI FBS UNY.

Berdasarkan hasil pengolahan, diperoleh data untuk menjawab hipotesis I, II, III, dan IV pada Tabel 6 berikut ini.
Tabel 6. Hasil Uji Beda Kelas A, B, C, dan D

\begin{tabular}{lccc}
\hline Data & $\mathrm{t}_{\text {hitung }}$ & df & Sig \\
\hline Kelas A Prates-Pascates & 10,495 & 36 & 0,000 \\
Kelas B Prates-Pascates & 4,681 & 34 & 0,000 \\
Kelas C Prates-Pascates & 1,231 & 36 & 0,226 \\
Kelas D Prates-Pascates & 2,501 & 32 & 0,018 \\
\hline
\end{tabular}

Probabilitas pengalaman membaca karya sastra antara hasil prates dengan pascates adalah 0,000 untuk kelas A dan B serta 0.018 untuk kelas $\mathrm{D}$, sedangkan kelas 0.226 . Artinya, $\mathrm{H}_{0}$ kelas A, B, dan D ditolak dan $\mathrm{H} 1$ kelas $\mathrm{A}, \mathrm{B}$, dan $\mathrm{D}$ diterima. Adapun $\mathrm{H}_{0}$ kelas $\mathrm{C}$ diterima dan $\mathrm{H} 1$ kelas $\mathrm{C}$ ditolak. Dengan kata lain, strategi tugas dan presentasi secara signifikan berpengaruh terhadap pengalaman membaca karya sastra mahasiswa untuk mahasiswa kelas A, B, dan D. Hal berbeda terjadi pada kelas $C$, yakni strategi tugas dan presentasi tidak berpengaruh secara signifikan terhadap pengalaman membaca karya sastra untuk kelas C.

\section{Pembahasan}

Ringkasan hasil penelitian menggambarkan beberapa hal. Pertama, peta awal pengalaman mahasiswa membaca karya sastra dalam jumlah buku karya sastra yang dibaca masih di bawah standar. Kedua, rerata skor pengalaman membaca karya sastra masih rendah. Ketiga, pengalaman membaca karya sastra dapat diperbaiki melalui pembelajaran berbasis strategi tugas dan presentasi.

Keempat kelas yang menjadi responden menunjukkan peningkatan yang tidak sedikit. Peningkatan kelas A sebesar 44,75, kelas B sebesar 18,88, dan kelas D sebesar 
10,41, kecuali kelas C yang peningkatannya hanya sebesar 8,48 . Di antara keempat kelas tersebut kelas A mengalami peningkatan yang paling besar, sedangkan yang mengalami peningkatan paling kecil adalah kelas C. Besarnya peningkatan skor dapat dipengaruhi oleh beberapa faktor, baik faktor internal maupun eksternal membaca sehingga dapat menimbulkan skor yang beragam dalam skor pengalaman membaca sastra pada mahasiswa. Faktor internal adalah rendahnya pengetahuan tentang betapa pentingnya membaca yang akan berdampak kepada faktor internal lain, yakni motivasi, kemauan, dan ketekunan. Faktor eksternal adalah pembelajaran yang dikembangkan di dalam perkuliahan. Salah satu faktor tersebut terkait dengan strategi pembelajaran yang dijadikan fokus dalam penelitian.

Hasil analisis hipotesis menyatakan bahwa terdapat perbedaan pengalaman membaca karya sastra sebelum menggunakan strategi tugas dan presentasi dengan setelah menggunakan strategi tugas dan presentasi. Hasil ini didasarkan atas penghitungan uji beda pada masing-masing kelas dengan probabilitas 0,05 . Jika probabilitas menunjukkan $>0,05$, berarti pengalaman membaca sastra mahasiswa sebelum mengikuti perkuliahan membaca sastra lebih baik dibandingkan dengan setelah mengikuti perkuliahan membaca karya sastra dengan strategi tugas dan presentasi. Ketika angka probabilitas menunjukkan $\leq 0,05$, berarti pengalaman membaca karya sastra mahasiswa sebelum mengikuti perkuliahan membaca sastra tidak lebih baik dibandingkan dengan setelah mengikuti perkuliahan membaca karya sastra dengan strategi tugas dan presentasi.
Hasil penghitungan statistika pada analisis hipotesis kedua menyatakan 3 (tiga) kelas menunjukkan angka $\leq 0,05,1$ (satu) kelas menunjukkan angka $>0,05$. Ketiga kelas itu adalah kelas A dengan probabilitas 0,000 yang berarti $\leq 0,05\left(\mathrm{H}_{0}=\mathrm{di}\right.$ tolak). Kedua yaitu kelas $\mathrm{B}$ dengan probabilitas 0,000 yang berarti $\leq 0,05\left(\mathrm{H}_{0}=\right.$ ditolak), dan kelas $\mathrm{D}$ dengan probabilitas 0,018 yang berarti $\leq 0,05\left(\mathrm{H}_{0}=\right.$ ditolak $)$. Adapun satu kelas, yakni kelas $\mathrm{C}$ dengan probabilitas 0,226 yang berarti $>0,05\left(\mathrm{H}_{0}\right.$ = diterima). Kesimpulan berdasarkan hasil uji beda per kelas dengan $\mathrm{H} 0$ tiga kelas ditolak dan $\mathrm{H} 0$ satu kelas diterima dapat dinyatakan bahwa pengalaman membaca karya sastra mahasiswa sebelum mengikuti perkuliahan membaca sastra tidak lebih baik dibandingkan dengan setelah mengikuti perkuliahan membaca sastra dengan strategi tugas dan presentasi ditolak untuk tiga kelas, dan $\mathrm{H} 0$ Kelas $\mathrm{C}$ diterima. Ketidaksignifikan kelas $\mathrm{C}$ juga dapat dipengaruhi oleh faktor internal dan eksternal membaca. Selain itu, peningkatan skor rerata membaca karya sastra setelah mendapatkan perlakuan menunjukkan peningkatan yang tidak terlalu besar dibandingkan dengan kelas yang lain.

Berdasarkan hasil di atas perkuliahan berbasis strategi tugas dan presentasi memberikan pengaruh terhadap pengalamam membaca karya sastra mahasiswa. Artinya, perkuliahan dengan strategi tugas dan presentasi dapat menjawab problematika rendahnya minat baca mahasiswa terhadap bacaan sastra. Strategi tugas dan presentasi dalam perkuliahan menjadi salah satu upaya dalam meningkatkan pengalaman membaca sastra khususnya bagi mahasiswa. Sementara itu, setelah mengikuti 
pembelajaran berbasis strategi tugas dan presentasi pengalaman mahasiswa membaca karya sastra mengalami peningkatan yang signifikan dari 0 buku karya sastra atau di bawah satu buku untuk puisi dan cerita pendek pada kelas A dan B menjadi di atas satu buku dan di bawah dua buku puisi dan cerita pendek untuk kelas D. $\mathrm{Hal}$ yang agak berbeda terjadi di kelas $\mathrm{C}$ dengan kondisi awal pengalaman membaca buku sastra puisi di bawah tujuh buku tetapi setelah perlakuan berada di bawah enam buku karya puisi.

Adanya peningkatan pengalaman membaca karya sastra mahasiswa memberi arti bahwa perkuliahan berbasis strategi tugas dan presentasi memberikan dampak positif bagi perubahan pengalaman membaca mahasiswa. Dampak tersebut berupa penambahan pengalaman dalam hal membaca karya sastra. Rerata pengalaman membaca karya sastra sebelum mendapatkan perlakuan adalah sebesar 31,37 dan lebih kecil daripada rerata pengalaman membaca sastra setelah mendapatkan perlakuan sebesar 50,2. Hal tersebut menunjukkan bahwa penerapan perkuliahan berbasis strategi tugas dan presentasi efektif memberikan pengaruh terhadap pengalaman membaca sastra mahasiswa. Namun, berbeda dengan kelas $\mathrm{C}$ yang peningkatannya tidak signifikan.

Mengapa kondisi awal pengalaman mahasiswa membaca karya sastra masih rendah? Dalam roadmap penelitian dan studi-studi terdahulu yang penulis (Suryaman, 2015, pp.184-185) lakukan kondisi awal mahasiswa dalam keadaan tidak siap untuk membaca karya sastra. Pertama, kemampuan membaca siswa Indonesia berada dalam kurva berkemampuan ren- dah. Kedua, kecenderungan siswa Indonesia menjawab soal berdasarkan tebakan, bukan berdasarkan budaya baca yang tinggi. Ketiga, sumber bacaan masih sangat langka berada dalam lingkungan siswa Indonesia. Jika pun ada, mutu bacaan kurang diperhatikan dari segi kualitas isi dan masalahnya. Keempat, pembelajaran membaca karya sastra di kelas belum mengedepankan pengembangan kompetensi membaca. Kelima, kebiasaan membaca karya sastra belum dikembangkan secara memadai. Keenam, teori sastra dalam pembelajaran membaca karya sastra yang diajarkan seringkali kurang tepat.

Kondisi awal pengalaman membaca karya sastra semasa di sekolah yang tidak siap tentunya akan berdampak kepada pengalaman dan kesiapan studi pada jenjang di perguruan tinggi. Seperti disarikan dari latar belakang masalah, temuan ini sangat mendukung keluhan dosen atas rendahnya pengalaman membaca karya sastra mahasiswa. Data yang menunjukkan bahwa pengalaman membaca karya sastra mahasiswa semester I nol buku karya sastra sebagai gambaran empiris betapa persoalan pengalaman membaca semasa di sekolah masih belum memenuhi standar minimal siswa wajib baca buku dan tamat. Hal ini sejalan pula dengan laporan UNESCO (2005) bahwa mahasiswa di negara maju rata-rata menghabiskan waktu 8 jam per hari untuk membaca buku, sedangkan mahasiswa di negara berkembang termasuk Indonesia, mahasiswanya rata-rata menghabiskan waktu 2 jam setiap hari.

Temuan yang sama dilaporkan oleh Swatikasari dan Pujiono (2017:108-109). Dalam laporan tersebut dinyatakan bahwa aktivitas membaca secara langsung berkisar 
antara $11 \%$ sampai dengan $60 \%$. Di dalam rentang waktu tersebut, hanya $11 \%$ mahasiswa yang melakukan kegiatan membaca secara rutin. Kegiatan rutin yang dimaksud adalah mahasiswa meluangkan waktu selama dua jam dalam sehari untuk membaca beragam buku.

Secara teori temuan penelitian ini juga relevan dengan asumsi yang dikemukakan oleh Effendi (1982:70) bahwa pengajaran sastra yang tepat adalah pengajaran yang memungkinkan kegiatan apresiasi sastra terbentuk. Strategi tugas dan presentasi yang secara signifikan berdampak kepada meningkatnya pengalaman membaca karya sastra mahasiswa menguatkan asumsi tersebut. Namun demikian, penelitian ini belum sampai pada kegiatan apresiasi yang yang komprehensif karena baru pada tahap membaca, sedangkan tahap apresiasi yang lain, seperti mempelajari teori sastra, mempelajari esei dan kritik sastra, mempelajari sejarah sastra, pendokumentasian informasi karya sastra, serta kegiatan kreatif menulis karya sastra dan menulis bahasan terhadap karya sastra belum diteliti secara mendalam. Faktor lain yang menyebabkan rendahnya pengalaman membaca karya sastra menurut Effendi (1982:70) adalah rendahnya ketersedian buku-buku sastra di perpustakaan sekolah. Kondisi ini turut menyumbang atas rendahnya budaya baca di sekolah yang berdampak pada tidak siapnya mereka saat memasuki perguruan tinggi (Litbang Kompas, (2007).

Secara metodologis, penelitian ini menghasilkan suatu eksperimen semu yang baik karena tanpa ada upaya pengelompokan terhadap subjek penelitian. Hipotesis bahwa strategi tugas dan presentasi berdampak positif dan signifikan terhadap pengalaman membaca karya sastra maha- siswa mencerminkan keberhasilan dari metode penelitian yang dipilih. Namun, satu hipotesis kerja ditolak ketika strategi tugas dan presentasi diterapkan di kelas C. Penolakan terhadap hipotesis ini sekaligus menggambarkan sisi lemah dari metode yang dipilih. Alasan penolakan belum teridentifikasi dengan baik. Dugaan sementara, strategi tugas dan presentasi serta metode eksperimen yang dipilih tidak tepat untuk mahasiswa kelas C. Kemungkinan lain adalah penelitian ini hanya dilakukan di empat kelas membaca sastra dengan setiap kelas berkisar antara 11 sampai dengan 19 mahasiswa, tidak semua mahasiswa dalam kelas menjadi responden. Keempat kelas tersebut dijadikan sebagai kelompok eksperimen dengan kontrolnya sebelum dan setelah perlakuan. Karena jumlah sampel relatif kecil ada kemungkinan berpengaruh terhadap hasil penelitian dan pengambilan keputusan. Akibatnya, hasil penelitian tidak dapat digeneralisasi untuk suatu ruang lingkup yang lebih luas. Untuk itu diperlukan penelitian replikasi dengan memakai sampel yang lebih banyak.

Kelemahan lain adalah materi yang dipilih sebagai materi perlakuan adalah adalah membaca puisi, novel, dan cerpen, sedangkan membaca drama tidak sempat dilakukan oleh karena waktu penelitian yang terbatas. Ada kemungkinan topik lain memberikan hasil yang berbeda dengan topik yang dijadikan sebagai materi perlakuan. Di samping itu, lamanya penelitian dalam memberikan perlakuan dalam penelitian ini relatif singkat sehingga kemungkinan perlakuan yang diberikan belum mendapatkan hasil yang optimal yang dapat mencerminkan pengalaman membaca sastra mahasiswa. 


\section{SIMPULAN}

Berdasarkan analisis dan pembahasan yang sudah dilakukan ada beberapa simpulan yang dapat dirumuskan. Pertama, peta awal pengalaman mahasiswa membaca karya sastra dalam jumlah buku karya sastra yang dibaca dalam keadaan yang tidak ideal karena seharusnya semasa di sekolah menengah atas seharusnya sudah membaca 10 karya sastra siswa SMP dan sederajat dan 15 siswa SMA sederajat dan bertambah berdasarkan standar Kurikulum 2013, yakni 25 siswa SMP dan 35 siswa SMA. Kedua, setelah mengikuti pembelajaran berbasis strategi tugas dan presentasi pengalaman mahasiswa membaca karya sastra mengalami peningkatan yang signifikan dari 0 buku karya sastra atau di bawah satu buku untuk puisi dan cerita pendek pada kelas A dan B menjadi di atas satu buku dan di bawah dua buku puisi dan cerita pendek untuk kelas D. Hal yang agak berbeda terjadi di kelas $\mathrm{C}$ dengan kondisi awal pengalaman membaca buku sastra puisi di bawah tujuh buku tetapi setelah perlakuan berada di bawah enam buku karya puisi. Ketiga, berdasarkan rerata skor pengalaman membaca karya sastra sebelum perlakuan yang kecil dibandingkan dengan setelah mendapatkan perlakuan dengan selisih skor yang signifikan, kecuali untuk kelas $C$ menguatkan bahwa strategi tugas dan presentasi memberikan dampak positif dalam hal pengalaman membaca sastra. Hal ini relevan dengan latar belakang masalah, teori, dan metode penelitian yang dipilih dalam analisis ini.

\section{UCAPAN TERIMA KASIH}

Tulisan dalam bentuk artikel ini dikembangkan dari penelitian di Fakultas
Bahasa dan Seni pada Tahun Anggaran 2014/2015 dengan Dana DIPA UNY tahun 2015. Dalam kesempatan ini izinkan penulis mengucapkan terima kasih kepada Fakultas Bahasa dan Seni serta Universitas Negeri Yogyakarta yang sudah mengalokasikan dana penelitian. Terima kasih juga penulis sampaikan kepada penelaah yang sudah memberikan masukan dan tanggapan untuk penyempurnaan hasil penelitian, khususnya kepada Dr. Anwar Efendi, M.Si.

\section{DAFTAR PUSTAKA}

Adler, M.J. dan Charles van Doren. 2007. How to Read a Book. Pernerj. A. Santoso dan Ajeng AP. Tanpa kota: iPublishing.

Effendi, S. 2004. Bimbingan Apresiasi Puisi. Jakarta: Pustaka Jaya.

Ismail, T. 2003. "Agar Anak Bangsa Tak Rabun Membaca tak Pincang Mengarang". Pidato Penganugerahan Gelar Kehormatan Doctor Honoris Causa di bidang Pendidikan Sastra, Universitas Negeri Yogyakarta.

Lasa Hs. 2006. "Penulisan Buku Teks Perguruan Tinggi". Makalah Workshop Strategi dan Teknik Penulisan Buku Teks Perguruan Tinggi tanggal 19 Juli 2006 di LPP UNS Surakarta.

Litbang Kompas. 2007. "Minat Baca Masyarakat Terhadang Daya Beli". Kompas, 19 Februari 2007.

Soedjiarto, 2008. Landasan dan Arah Pendidikan Nasional Kita. Jakarta: Kompas.

Suryaman, M. 2015. "Analisis Hasil Belajar Peserta Didik dalam Literasi membaca melalui Studi Internasional (PIRLS) 2011". Litera Jurnal Penelitian Bahasa, Sastra, dan Pengajarannya, Volume 14, Nomor 1, April 2015, hlm. 184-185 . 
Swatikasari, E. dan Setiawan P. 2012. "Budaya Literasi di Kalangan Mahasiswa FBS UNY". Dalam Litera Jurnal Penelitian Bahasa, Sastra, dan Pengajarannya, Volume 16, Nomor 1, April 2017, hlm. 108-109.

Teeuw, A. 1994. Indonesia Antara Kelisanan dan Keberaksaraan, Jakarta: Pustaka Jaya.

UNESCO. 2005. Global Monitoring Report 2006: Education for All Education for All Literacy for Life, France: United Nations Educational, Scientific and Cultural Organization 7. 